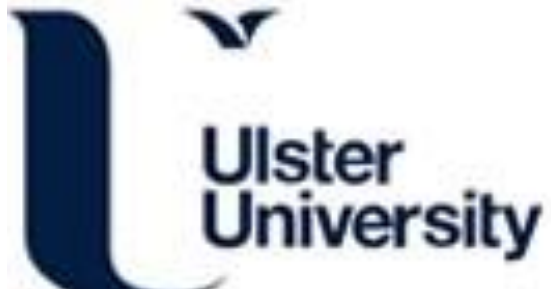

\section{Antioxidant Activity of Curcumin and Neem (Azadirachta indica) Powders: Combination Studies with ALA Using MCF-7 Breast Cancer Cells}

Cheung, T., Singh - Nee Nigam, P., \& Owusu-Apenten, R. (2016). Antioxidant Activity of Curcumin and Neem (Azadirachta indica) Powders: Combination Studies with ALA Using MCF-7 Breast Cancer Cells. Journal of Applied Life Sciences International, 4(3), 1-12. https://doi.org/10.9734/JALSI/2016/22273

Link to publication record in Ulster University Research Portal

Published in:

Journal of Applied Life Sciences International

Publication Status:

Published (in print/issue): 08/01/2016

DOI:

10.9734/JALSI/2016/22273

Document Version

Publisher's PDF, also known as Version of record

\section{General rights}

Copyright for the publications made accessible via Ulster University's Research Portal is retained by the author(s) and / or other copyright owners and it is a condition of accessing these publications that users recognise and abide by the legal requirements associated with these rights.

\section{Take down policy}

The Research Portal is Ulster University's institutional repository that provides access to Ulster's research outputs. Every effort has been made to ensure that content in the Research Portal does not infringe any person's rights, or applicable UK laws. If you discover content in the Research Portal that you believe breaches copyright or violates any law, please contact pure-support@ulster.ac.uk. 


\title{
Antioxidant Activity of Curcumin and Neem (Azadirachta indica) Powders: Combination Studies with ALA Using MCF-7 Breast Cancer Cells
}

\author{
T. K. N. Cheung ${ }^{1}$, P. Singh Nigam ${ }^{1}$ and R. Owusu-Apenten ${ }^{1 *}$ \\ ${ }^{1}$ School of Biomedical Sciences, Ulster University, Cromore Road, Coleraine BT52 1SA, UK.
}

Authors' contributions

This work was carried out in collaboration between all authors. Authors ROA and PSN designed the study and wrote the protocol. Author TKNC wrote the first draft of the manuscript. Author TKNC managed the literature searches and the experimental process. All authors read and approved the final manuscript.

Article Information

DOI: 10.9734/JALSI/2016/22273

Editor(s):

(1) Shahira M. Ezzat, Department of Pharmacognosy, Faculty of Pharmacy, Cairo University,

Egypt.

Reviewers:

(1) Upendarrao Golla, Indian Institute of Science Education and Research, Bhopal, India

(2) Patricia Gonzalez-Barranco, Universidad Autonoma de Nuevo Leon, Mexico.

(3) Intan Soraya Che Sulaiman, Universiti Putra Malaysia, Malaysia. (4) Mary Ann Foglio, Universidade Estadual de Campinas, Brazil. Complete Peer review History: http://sciencedomain.org/review-history/12881

Original Research Article

Received 26 $6^{\text {th }}$ September 2015 Accepted $3^{\text {rd }}$ December 2015 Published $4^{\text {th }}$ January 2016

\section{ABSTRACT}

Introduction: Breast cancer is the most common cancer affecting women globally. The essential fatty acid $\alpha$-Linolenic acid (ALA) and its oxidation products inhibit cancer cell proliferation. The effect of natural antioxidants on ALA anticancer effects has not been well characterized.

Aims: To assess the effect of curcumin and neem leaf powder extract, on ALA cytotoxicity activity towards MCF-7 breast cancers.

Study Design: In-vitro testing.

Methodology: Antioxidant activity of neem extract and curcumin were evaluated using, four assays: Total phenolic content, Ferric reducing antioxidant power (FRAP), 2, 2-diphenyl-1picrylhydrazyl (DPPH) assay or 2, 2'-azino-bis-3-ethylbenzthiazoline-6-sulphonic acid (ABTS) assay. Cytotoxicity activity was assessed using MCF7 cells grown in DMEM (+10\% FBS) and evaluated using Sulforhodamine B colorimetric assay for cell cytotoxicity. 
Results: Curcumin and neem leaf extract had significant antioxidant power, and values varied between the four assays. Treatments of MCF7 cells with ALA, (0-500 $\mu \mathrm{M})$ curcumin $(0-50 \mu \mathrm{M})$, and neem leaf extract (0-88 $\mu \mathrm{M})$ individually produced a concentration-dependent decrease in MCF-7 cell viability. Combination treatments using ALA with curcumin and ALA with neem were significantly less effective compared to individual treatments.

Conclusion: Combinations studies indicate that the natural antioxidants curcumin and neem reduce the inhibitory effect of $\alpha$-Linolenic acid towards MCF-7 breast cancer cells.

Keywords: Antioxidant; total phenols; curcumin, neem (Azadirachta indica), linolenic acid; MCF-7 cell; anticancer.

\section{INTRODUCTION}

Cancer is a debilitation disease that afflicts a noticeable proportion of the world population in all generations. Breast cancer is the most common cancer among women globally with 1.67 million new cases diagnosed in 2012 and accounting for $25 \%$ of all cancers [1]. Diet is a moderating factor for cancer risk and high intakes of marine and fish derived n-3 fatty acids were associated with reduced risk of cancer though the relations are controversial [2]. Past investigations showed that Essential Fatty Acids (EFAs) inhibit the proliferation breast cancer cells $[3,4]$ and that lipid peroxidation products may be implicated; reviewed in [5-8]. Alpha-Linolenic acid (ALA) is an unsaturated fatty acid that is essential for humans since it is not produced within the human body. Dietary ALA is converted to Eicosapentaenoic Acid (EPA), and Docosahexaenoic Acid (DHA) but the conversion rate may be variable depending on a range of factors including age [9]. Breast cancer cells have an increased requirement for $n-3$ fatty acids owing to a low D6 desaturase activity for converting ALA to EPA and DHA $[3,8]$.

Recent attention has focused on antioxidants, herbals and traditional medicines from natural sources [10]. Curcumin from the spice turmeric expresses anticancer activity via multiple pathways linked with inflammation signaling, cell proliferation, invasion, cell death and gene expression (reviewed in [11-14]) and is currently undergoing Phase I-II clinical trials [13]. Neem (Azadirachta indica) leaf has been a traditional herbal agent for therapeutic and agricultural uses [15-17]. Recent investigations noted significant in-vitro antioxidant and free radical quenching activity for curcumin [18-22] and neem [23-27]. However, no single study comparing the antioxidant capacity of curcumin and neem using a range of antioxidant assays have been published.
The anticancer effects of $n-3$ polyunsaturated fatty acids (PUFA) are partly attributed to lipid hydroperoxides formed by enzymatic or nonenzymatic oxidation, which processes are inhibited by the antioxidant vitamin $E$ [28-30]. Currently, the majority of investigations of $n-3$ fatty acids and MCF-7 breast cancer cells focused on DHA and EPA rather than ALA. Invitro tests using MCF-7 cells treated with curcumin [31-35] or neem leaf extract [36] showed anti-proliferative activity but the modes of action are not understood. No reported studies have considered the effect of curcumin or neem leaf extract on ALA anticancer activity. Herbal agents may exhibit a pro-oxidant or antioxidant effect depending on their concentrations and so the consequences of combining such compounds with ALA are uncertain. The hypothesis tested in this study was that, combination treatments with ALA and natural antioxidants will affect cytotoxicity activity towards MCF-7 breast cancer cells. To address current research gaps, the aims of this study were; (a) to examine antioxidant activity of curcumin and neem leaf powder using a variety of in-vitro assays, and (b) to examine the effect of ALA, curcumin and neem leaf extracts on breast cancer cell proliferation individually and in combination.

\section{MATERIALS AND METHODS}

\subsection{Materials}

Curcumin powder (>98\% pure) was purchased from Sigma-Aldrich. All additional reagents were analytical grade, purchased from SigmaAldrich and used as received. Neem (Azadirachta indica) leaf powder was originally produced in India, and supplied by TOP-OP (Foods) Ltd, MIDDX, UK (www.top-op.com) and phosphate buffered saline (PBS) was obtained from Oxoid Ltd. 


\subsection{Antioxidant Assays}

\subsubsection{Instrumentation}

Colorimetric measurements were recorded using a UV/ Visible spectrophotometer (Ultrospec 2000, Pharmacia Biotech, Uppsala Sweden) in conjunction with 1-cm polystyrene cuvettes (Sarsted Ltd., Leicester, UK). All microplate assays involved a 96-microplate reader (VERSAmax; Molecular devices, Sunnydale, California, USA) used with flat-bottomed 96-well microplates (NUNC, Sigma Aldrich, UK).

\subsubsection{Sample extractions and reference antioxidants preparation}

Curcumin powder $(51 \mathrm{mg}$ ) was dissolved in $50 \mathrm{ml}$ of methanol and the mixture was centrifuged. Neem leaf extract was prepared by stirring $1 \mathrm{~g}$ of power with $9 \mathrm{~g}$ of distilled water then transferring $1 \mathrm{ml}$ of the mixture to another $9 \mathrm{~g}$ of distilled water. The mixture was centrifuged and the solids-content for the supernatant was determined by oven drying. Curcumin or neem leaf extracts were diluted using distilled water or PBS and analyzed for total antioxidant capacity (TAC) and total phenolic content (TPC) as described below.

\subsubsection{Ferric Reducing Antioxidant Potential (FRAP) assay}

The ferrozine ferric reducing antioxidant power (FRAP) assay is based on the reducing power of a sample. It measures the reduction of $\mathrm{Fe} 3+$ (ferric iron) to $\mathrm{Fe} 2+$ (ferrous iron) and detection using ferrozine as dye. A ferrozine FRAP assay was used in this study as described by Butts and Mulvihill [37] with slight modifications. The assay was performed at $\mathrm{pH} 7.0$ using Tris buffer and using ferric ammonium citrate in place of ferric chloride. Curcumin extracts (diluted 1-16 fold, $\left.D_{F}=1-16\right)$ and neem leaf extracts $\left(D_{F}=10-320\right)$ were prepared as previously described. Diluted samples $(20 \mu \mathrm{l})$ were added to 96 micro-well plates, $280 \mu \mathrm{l}$ of ferrozine working solution was added, and samples were incubated for $30 \mathrm{~min}$ at $37^{\circ} \mathrm{C}$. Absorbance measurements were recorded at $562 \mathrm{~nm}$ using a microplate reader.

\subsubsection{The 2.2-diphenyl-1-picryhydrazyl free radical scavenging assay}

The 2.2-diphenyl-1-picryhydrazyl (DPPH) assay was modified from [38,39]. Briefly, a
DPPH working solution was prepared by diluting $10 \mathrm{ml}$ of DPPH stock $(24 \mathrm{mg}$ in $100 \mathrm{ml}$ methanol) with $45 \mathrm{ml}$ methanol to reach the initial absorbance of $0.7 \pm 0.03$ at $515 \mathrm{~nm}$ using a $1 \mathrm{~cm}$ spectrophotometer. Curcumin extracts $\left(D_{F}=1-16\right)$ and neem leaf extracts $\left(D_{F}=40-1000\right)$ were prepared as previously mentioned. Diluted samples $(20 \mu \mathrm{l})$ were added to 96 micro-well plate and $280 \mu \mathrm{l}$ of DPPH solution was added into the plate. The mixtures were incubated in darkness for $30 \mathrm{~min}$ at $37^{\circ} \mathrm{C}$ and then absorbance measurements were recorded at $515 \mathrm{~nm}$ using a microplate reader.

\subsubsection{The 2,2-azinobis (3-ethyl- benzothrazoline-6-sulfonic acid radical cation de-colorization assay}

The 2,2-azinobis (3-ethyl-benzothrazoline-6sulfonic acid (ABTS) assay was modified from [40]. Briefly, 27.4 mg of ABTS and $2 \mathrm{mg}$ of sodium persulfate were dissolved with $90 \mathrm{ml}$ and $10 \mathrm{ml}$ of phosphate-buffer saline (PBS), respectively. The ABTS working solution was prepared in $100 \mathrm{ml}$ volumetric flask by mixing ABTS and sodium persulfate stock solutions and storing in the dark overnight at room temperature. Before use, ABTS solutions were diluted with PBS until to an initial absorbance value of 0.85 at $734 \mathrm{~nm}$ using a $1 \mathrm{~cm}$ spectrophotometer. For sample analysis $(20 \mu \mathrm{l})$ of curcumin $\left(D_{F}=1-75\right)$ or neem leaf extracts $\left(D_{F}=10-1000\right)$ were added to 96 microwell plate and $280 \mu \mathrm{l}$ of ABTS solution was added. The mixtures were incubated for $30 \mathrm{~min}$ at $37^{\circ} \mathrm{C}$ and then absorbance measurements were recorded at $734 \mathrm{~nm}$ using a microplate reader.

\subsubsection{Total phenolic content}

Total phenolic contents (TPC) were determined using the Folin-Denis method modified from [41]. The diluted samples $(50 \mu \mathrm{l})$ of curcumin $\left(D_{F}=1-16\right)$ or neem leaf extracts $\left(D_{F}=10-160\right)$ were added to micro-centrifuge tube, followed by $100 \mu \mathrm{l}$ of Folin-Denis regent, $800 \mu \mathrm{l}$ of sodium carbonate reagent and $50 \mu \mathrm{l}$ of methanol. The samples were vortexed gently, incubated at $37^{\circ} \mathrm{C}$ for $20 \mathrm{~min}$ and centrifuged at $11,000 \mathrm{rpm}$ for $5 \mathrm{~min}$. The clear supernatant $(200 \mathrm{ul})$ were transferred to 96 micro-well plates and absorbance was measured at $760 \mathrm{~nm}$ using a microplate reader. 


\subsection{Cytoxcity Assay}

\subsubsection{Cell culture}

MCF-7 cells (American Type Cell Culture) were cultured in Dulbecco's modified eagle's medium (DMEM; GIBCO) with 10\% fetal bovine serum (FBS), $1 \% \mathrm{w} / \mathrm{v}$ penicillin streptomycin (Pen Strep) and $1 \%$ minimum essential medium nonessential amino acids (MEM NEAA). Culture flasks and 96-microwell plates were incubated in a humidified incubator at $37^{\circ} \mathrm{C}$ in $\mathrm{O} 2$ 95\% $5 \%$ CO2. (LEEC research incubator, LEEC, UK). Cells were trypsinised, counted using a NucleoCounter (NC-3000, ChemoMetec, Denmark) and seeded (10,000 cells/well) in 96microwell plates with $50 \mu \mathrm{l}$ of culture medium overnight to allow cell attachment. Cell growth was monitored using the Sulforhodamine B assay for cell cytotoxicity (see below).

\subsubsection{In-vitro cytotoxicity tests}

Curcumin and ALA ( $\geq 99 \%$ pure) were diluted in methanol (HPLC grade, $\geq 99.9 \%$ ) to make $10 \mathrm{mM}$ stock solutions. Neem leaf extracts were prepared as above (section 2.2.2) and their concentrations were determined by the TPC method in terms of gallic acid equivalence. Stock solutions were then diluted with culture medium 10-fold for curcumin and neem leaf extracts and 5-fold for ALA, and filter sterilized with 0.20- $\mu \mathrm{m}$ cellulose acetate filters. The sterile solution of curcumin, neem leaf extract or ALA was further diluted with culture medium. Cells were treated with various concentrations of curcumin (0-100 $\mu \mathrm{M})$, neem leaf extracts $(0-176 \mu \mathrm{M})$ or ALA (0$1000 \mu \mathrm{M} ; 50 \mu \mathrm{l})$ and incubated at $37^{\circ} \mathrm{C}$ for $72 \mathrm{hr}$. The final concentration of methanol for treated cells was less than $0.1 \%$ which is non-toxic to MCF-7 cells. For the control study, cells were treated with culture medium only. For combination studies, cells were treated with 50:50 mixtures prepared using $4 \mathrm{x}$ the desired "within-well" concentrations of ALA with neem extract, or ALA with curcumin. All other techniques were as described previously.

\subsubsection{Sulforhodamine B (SRB) Assay for cell cytotoxicity}

The sulforhodamine B (SRB) assay for cytotoxicity is a colorimetric assay to determine cell numbers based on the detection of cell proteins [42]. Cells were treated as previously mentioned. The cells were fixed with $100 \mu$ of cold 10\% (w/v) Trichloroacetic Acid (TCA) and incubated at $5^{\circ} \mathrm{C}$ for an hour. After four washings with tap water and air-drying, the cells were stained for $30 \mathrm{~min}$ at room temperature with $0.06 \%$ SRB dye solution dissolved in $1 \%$ acetic acid (100 $\mu \mathrm{l} /$ well) and subsequently rinsed four times with $1 \%(\mathrm{v} / \mathrm{v})$ acetic acid to remove unbound stain. After drying, Trizma-base (200 $\mu \mathrm{l} /$ well, $10 \mathrm{mM}$ ) was added to the plate to solubilize SRB dye, and the plates were shaken using an Orbital Shaker for 5 min (Speed: 180 $\mathrm{revs} / \mathrm{min})$. Absorbances were measured at $564 \mathrm{~nm}$ using a microplate reader and the data was transferred to MS excel and SPSS for further analyses. Cell viability was calculated as a percentage of absorbance readings for cells treated with vehicle.

\subsection{Data Analysis}

\subsubsection{ABTS and DPPH data reduction}

The following equations illustrate $\mathrm{IC}_{50}$ determination for the ABTS and DPPH methods;

$$
\begin{aligned}
& \Delta \text { Absorbance }=\left[\left(A_{\text {CONTROI }}-A_{\text {SAMPLE }}\right)\right. \\
& \begin{aligned}
& \% \text { inhibition }= {\left[\left(A_{\text {CONTROI }}-A_{\text {SAMPLE }}\right) / A_{\text {CONTROL }}\right] \times } \\
& 100 \%
\end{aligned}
\end{aligned}
$$

where $A_{C O N T R O L}$ is the initial absorbance of the ABTS or DPPH working reagent and $A_{\text {SAMPLE }}$ is the absorbance after incubation with curcumin or neem leaf extracts for 30 minutes. The concentration of antioxidant that neutralizes $50 \%$ of ABTS or DPPH radicals $\left(\mathrm{IC}_{50}\right)$ was determined from the relation, $I_{50}=50 /$ GRAD, where GRAD is the gradient for a graph of \% ABTS inhibition (Y-axis) plotted versus concentration ( $\mathrm{x}$ - axis) [43].

\subsubsection{Sensitivity, precision, and minimum detectable concentrations for antioxidants}

The assay sensitivity was determined from the gradient (GRAD) of calibration graphs where absorbance is plotted versus gallic acid or trolox concentration. Values for the GRAD $\left(\mathrm{M}^{-1}\right)$ were subjected to pathlength correction to convert to the molar absorptivity $\left(\varepsilon, \mathrm{M}^{-1} \mathrm{~cm}^{-1}\right)$ as described recently; $\varepsilon=$ GRAD/ $L$ (cm) where $L=$ pathlength for microplate reader [44]. Under the conditions of this study $L=0.5 \mathrm{~cm}$ (TPC method) or $L=0.8$ $\mathrm{cm}$ (FRAP, DPPH, ABTS methods). The error of analysis was determined by the average coefficient of variation (CV\%), where $\mathrm{CV} \%=$ (SD/Mean) x 100\%) using values for mean and 
standard deviation (SD) for measurements. All analytical procedures had a measure for within and between assay precision. The minimum detectable concentration (MDC) is the least concentration of antioxidant that is detectable above the background noise. MDC was determined from [45] the relation,

$$
\mathrm{MDC}=3.0 \mathrm{SD}_{0} / \mathrm{GRAD}
$$

where $\mathrm{SD}_{0}$ is the standard deviation for analysis using a reagent "blank" $(0 \mu \mathrm{M})$ and GRAD is the gradient of calibration graph. The upper limit of detection (ULD) for antioxidants was determined as the highest concentration of reference antioxidant, for which r-squared $\left(R^{2}\right)$ is close to 1.0. The concentration range between MDC and ULD represents the linear dynamic range for assays.

\subsubsection{Total antioxidant capacity for neem and curcumin samples}

The antioxidant capacity of curcumin and neem leaf extracts were determined in terms of trolox equivalents (TE: $\mathrm{mmol} / \mathrm{g}$ ) and gallic acid equivalents (GAE: $\mathrm{mmol} / \mathrm{g}$ ) using the relation,

$$
T E A C / G A E A C=\frac{\triangle A}{G R A D} * \frac{A_{v}}{S p_{v}} * D_{F} * \frac{1}{C_{e x t}} * 10^{5}
$$

where $\Delta \mathrm{A}=$ absorbance change corrected for the reagent blank, $A_{v}=$ total assay volume $(300 \mu \mathrm{l})$, $S p_{v}=$ sip volume $(20 \mu l)$ of sample analyzed, $\mathrm{C}_{\text {ext }}=$ concentration of curcumin / neem leaf extracts $(g / l), D_{F}=$ dilution for extracts prior to analysis $\left(D_{F}=1\right.$ for undiluted extract). To express antioxidant activity in terms of trolox/ gallic acid equivalent antioxidant activity (TE/ GAE; mmol/g) then GRAD from the trolox/gallic acid calibration graph was inserted into equation 4.

\subsubsection{Statistical analysis}

All experiments were repeated on 3 different occasions with $12-48$ replicates per drug concentration. Routine data analysis were conducted using MS excel. One-way analysis of variance ANOVA tests were performed by Microsoft SPSS version 22 (IBM Corporation) with Tukey post hoc analysis for the separation of means. $P<0.05$ was considered to be statistically significant. Paired t-tests were performed on a calculator at www.graphpad.com.

\section{RESULTS}

\subsection{Antioxidant Activities}

Extracts of curcumin prepared using methanol and neem prepared using water had a solids content of $0.9(\mathrm{mg} / \mathrm{ml})$ and $30.2(\mathrm{mg} / \mathrm{ml})$. The corresponding percentage yield of extraction was $90 \%$ and $30 \%$. Fig. 1 shows four calibration graphs for antioxidant assays used in this study, with gallic acid reference. All assays had linear responses with coefficients of regression $\left(R^{2}\right)>$ 0.96. The data were fitting a straight-line equation $(Y=x$. GRAD) where, $Y=$ absorbance and $\mathrm{x}=$ concentration of antioxidant, and GRAD $=$ slope of the line. Based on the molar absorptivity $\left(\varepsilon,\left(\mathrm{M}^{-1} \mathrm{~cm}^{-1}\right)\right.$ value for gallic acid (Table 1) the order of assay sensitivity was; $\mathrm{DPPH}>\mathrm{TPC}>\mathrm{ABTS}>\mathrm{FRAP}$ assay. By comparison, the order of sensitivity using trolox as reference antioxidant was; ABTS $>$ DPPH > TPC > FRAP assay (Table 1). The MDC and other assay parameters are reported in Table 1. For gallic acid as reference antioxidant the within-assay precision (CV\%) for the TPC, FRAP, DPPH or ABTS assay was $6.0 \%, 1.3 \%$, $4.5 \%$ or $2.3 \%$, respectively. Using trolox as reference, the within-assay $\mathrm{CV} \%$ for TPC, FRAP, DPPH or ABTS assay was, $7.5 \%, 1.9 \%, 4.4 \%$ or $1.4 \%$ respectively. The between-days CV\% for the assays is shown in Table 1.

The antioxidant capacity for curcumin and neem leaf extract expressed as TE (Fig. 2) or GAE (Table 2) varied according to the type of assay adopted.

From Table 2, the highest antioxidant capacity estimates were observed with the FRAP assay for neem. The other assays produced an antioxidant capacity of 22-30.4 (mmol GAE/100 g) for neem powder and 16-54 (mmol GAE/100 g) for curcumin. For neem leaf extract, antioxidant capacity determined with the TPC and ABTS assay were not significantly different (Table 2). Likewise, for curcumin, the TPC / FRAP and also ABTS/ $\mathrm{DPPH}$ were statistically similar. In Table 2, the numbers of samples ( $\mathrm{N} \ddagger$ ) varied between the four different assays. All measurements involved at least 3 replicate experiments and multiple dilutions of test samples to reduce the effect of sample colour. Data showing no significant difference for the results from different dilution were averaged. Alternatively, where there was a significant difference due to sample dilution then 
the highest antioxidant capacity (GAE/TE) were used as representative data (Table 2 and estimates, normally obtained at higher dilutions, Fig. 2).

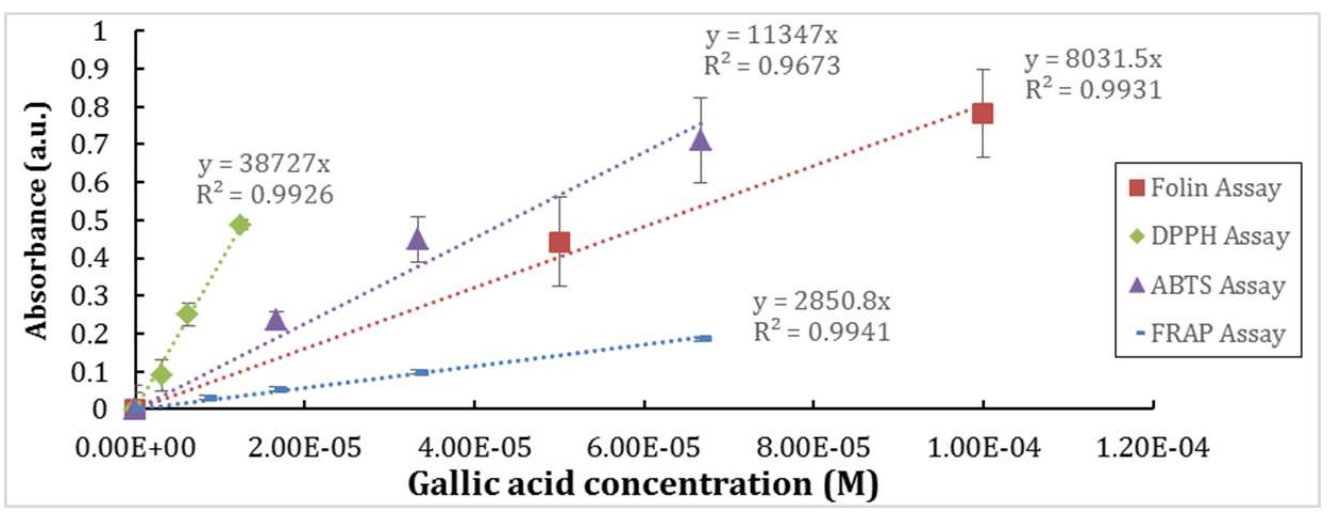

Fig. 1. Antioxidant capacity assays using gallic acid

Notes: Gallic acid as standard compound. TPC =Folin-Denis assay, FRAP =Ferric reducing antioxidant potential assay, $D P P H=2$, 2-diphenyl-1-picrylhydrazyl assay, $A B T S=(2$, 2'-azino-bis-3-ethylbenzthiazoline-6-sulphonic acid assay. For all assays absorbance were read different wave-lengths of $760 \mathrm{~nm}$ (TPC), $562 \mathrm{~nm}$ (FRAP assay), $515 \mathrm{~nm}$ (DPPH assay) and $734 \mathrm{~nm}$ (ABTS assay)

Table 1. Characteristics of four different antioxidant assays used in this study

\begin{tabular}{|c|c|c|c|c|c|c|c|c|c|c|}
\hline \multirow{3}{*}{$\begin{array}{l}\text { Assays } \\
*\end{array}$} & \multicolumn{5}{|c|}{ Gallic acid } & \multicolumn{5}{|c|}{ Trolox standard } \\
\hline & \multicolumn{2}{|c|}{$\varepsilon,\left(\mathbf{M}^{-1} \mathbf{c m}^{-1}\right)$} & \multirow[t]{2}{*}{$\mathbf{R}^{2} \ddagger$} & \multirow{2}{*}{$\begin{array}{l}\text { CV } \\
(\%)\end{array}$} & \multirow{2}{*}{$\begin{array}{l}\text { MDC† } \\
(\mu \mathrm{M})\end{array}$} & \multicolumn{2}{|c|}{$\varepsilon,\left(\mathbf{M}^{-1} \mathbf{c m}^{-1}\right)$} & \multirow[t]{2}{*}{$\mathbf{R}^{2} \ddagger$} & \multirow{2}{*}{$\begin{array}{l}\text { CV } \\
\text { (\%) }\end{array}$} & \multirow{2}{*}{$\begin{array}{l}\text { MDC } † \\
(\mu \mathrm{M})\end{array}$} \\
\hline & Mean & SEMO & & & & Mean & SEMO & & & \\
\hline$\overline{\text { FRAP }}$ & 3564 & 90 & 0.994 & 7.8 & 6.5 & 450 & 13 & 0.995 & 3.4 & 50.4 \\
\hline ABTS & 14184 & 896 & 0.967 & 10.8 & 2.5 & 12169 & 205 & 0.997 & 7.5 & 2.8 \\
\hline TPC & 16062 & 582 & 0.993 & 15.9 & 23.2 & 4464 & 206 & 0.981 & 8.8 & 20.8 \\
\hline DPPH & 48409 & 1609 & 0.997 & 6.3 & 4.8 & 10325 & 564 & 0.974 & 7.7 & 16.6 \\
\hline
\end{tabular}

* Abbreviations: TPC assay= Folin-Denis assay, FRAP assay= Ferric reducing antioxidant potential assay, $D P P H$ assay= 2, 2-diphenyl-1-picrylhydrazyl assay, ABTS assay = 2,2'-azino-bis-3-ethylbenzthiazoline-6sulphonic acid assay; $(\Theta)$ Molar absorptivity $(\varepsilon)$ is mean (+/-) standard error $(S E M),(\ddagger) R^{2}$ equal to $r$-squared values that range from 0 to 1 , while 0 representing no statistical correlation between the data and a line, and 1 representing completely fit between the data and the line drawn through them, $(\dagger) M D C=$ Minimum Detectable Concentration

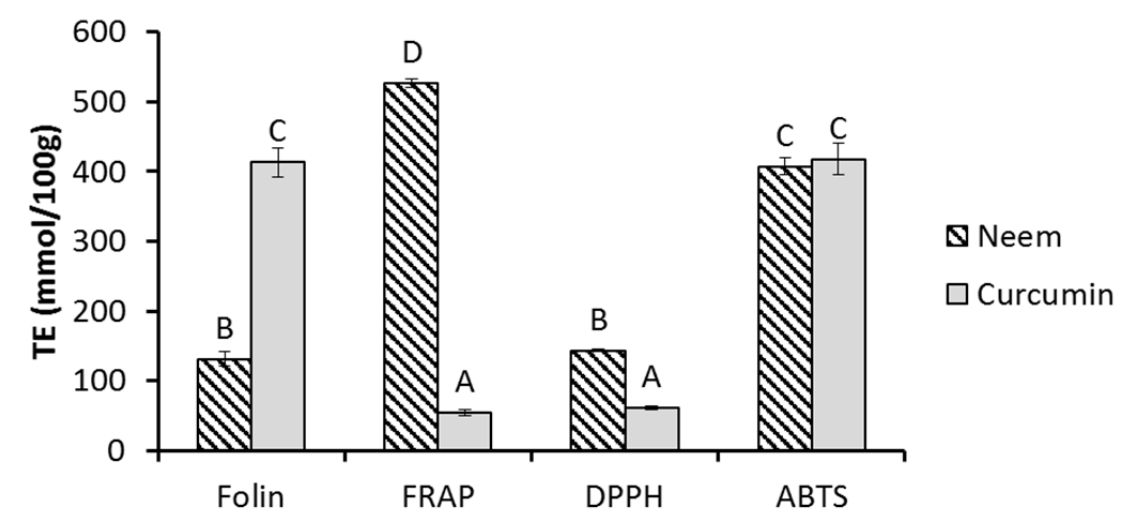

Fig. 2. Effect of assay method on antioxidant capacity of neem (Azadirachta indica) extract and curcumin expressed as trolox equivalent (TE)

Assays were, total phenols (TPC-), FRAP (Ferric reducing antioxidant potential), DPPH (2, 2-diphenyl-1picrylhydrazyl), and ABTS (2,2'-azino-bis-3-ethylbenzthiazoline-6-sulphonic acid) methods. Bars show means+/SEM, different letters show significant differences $(P<0.05)$ 
Table 2. Antioxidant capacity of neem (Azadirachta indica) and curcumin as Gallic Acid Equivalents (GAE)

\begin{tabular}{llllll}
\hline Assay method * & N\$ & \multicolumn{2}{c}{$\begin{array}{c}\text { Neem leaf powder } \\
\text { (GAE, mmol/100 g) }\end{array}$} & \multicolumn{2}{c}{$\begin{array}{c}\text { Curcumin } \\
\text { (GAE, mmol/100 g) }\end{array}$} \\
\cline { 2 - 6 } & & Mean & SEMO & Mean & SEMO \\
\hline TPC & 96 & $27.1^{\mathrm{a}}$ & 2.0 & $51.4^{\mathrm{b}}$ & 2.0 \\
FRAP & 56 & $540.8^{\mathrm{c}}$ & 7.0 & $54.2^{\mathrm{b}}$ & 4.0 \\
DPPH & 40 & $30.4^{\mathrm{b}}$ & 0.0 & $16.0^{\mathrm{a}}$ & 0.0 \\
ABTS & 87 & $22.0^{\mathrm{a}}$ & 1.0 & $23.4^{\mathrm{a}}$ & 1.0 \\
\hline
\end{tabular}

* Abbreviations: TPC assay = Folin-Denis assay, FRAP assay = Ferric reducing antioxidant potential assay, $D P P H$ assay= 2, 2-diphenyl-1-picrylhydrazyl assay, ABTS assay = 2,2'-azino-bis-3-ethylbenzthiazoline-6sulphonic acid assay, GAE = Gallic acid equivalent antioxidant capacity, TE = Trolox equivalent antioxidant, capacity, $(\Theta) S E M=$ standard error of mean, $(\ddagger) N=$ number of samples. (a-e) Columns with different letters are significantly different $(p<0.05)$

In other studies, we found the concentration of curcumin and neem leaf extract necessary for $50 \%$ inhibition $\left(\mathrm{IC}_{50}\right)$ of ABTS was $7.5(\mu \mathrm{g} / \mathrm{ml})$ and $1.7(\mu \mathrm{g} / \mathrm{ml})$ respectively. By comparison, the $\mathrm{IC}_{50}$ values for inhibition of DPPH radicals was $7.8(\mu \mathrm{g} / \mathrm{ml})$ and $3.8(\mu \mathrm{g} / \mathrm{ml})$ for curcumin and neem leaf extracts, respectively. Based on the values for $\mathrm{IC}_{50}$, neem leaf extract showed $\sim 4$ times greater ABTS inhibition or 2-times greater $\mathrm{DPPH}$ inhibition compared to the equivalent concentration $(\mu \mathrm{g} / \mathrm{ml})$ of curcumin. The $I_{50}$ values are given as the actual concentrations in the reaction system.

\subsection{Cell Viability}

In Fig. 3, treatment of MCF-7 cells with ALA (0$500 \mu \mathrm{M})$ or neem leaf extract $(0-88 \mu \mathrm{M}, \mathrm{GAE})$ produced a concentration-dependent decrease of cell viability. The final panel in Fig. 3 shows that the losses of cell viability were less severe if cells were treated with a combination of neem plus ALA as compared to each of these agents individually.

Fig. 4 shows MCF-7 cell treatments with curcumin $(0-50 \mu \mathrm{M})$, ALA $(0-500 \mu \mathrm{M})$, or their combinations. The concentrations of the individual agents required to inhibit MCF-7 cells by $50 \%\left(\mathrm{IC}_{50}\right)$ were estimated (from Figs. 3 and 4) as $50 \mu \mathrm{M}$ for ALA whilst $\mathrm{IC}_{50}=17.8 \mu \mathrm{M}$ GAE for neem extract and $\mathrm{IC}_{50}=7.2 \mu \mathrm{M}$ for curcumin. There were significantly lower decreases of cell viability for combination treatments, whilst the individual treatments using ALA, or curcumin produced higher inhibitions of MCF-7 cells.

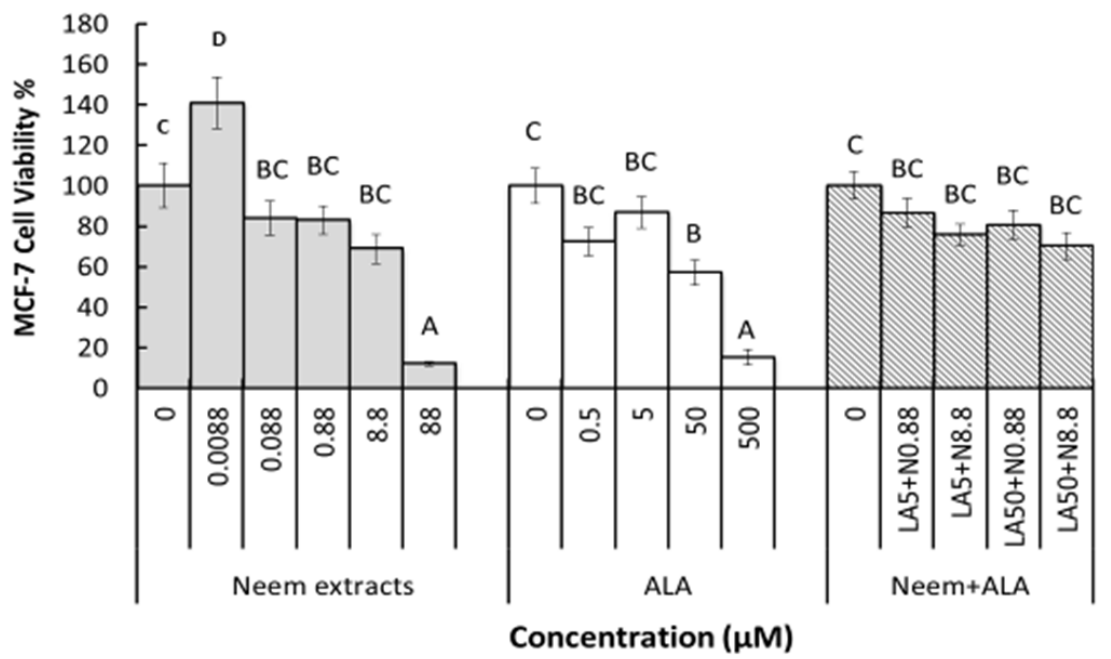

Fig. 3. Effect of neem, $\alpha$-Linolenic acid or their combination on MCF-7 cell viability MCF-7 cells were treated with neem leaf extract $(0-88 \mu \mathrm{M}), A L A(0-500 \mu \mathrm{M})$, or combinations for $72 \mathrm{hr}$. Bars show means $+/-$ SEM. Different letters indicate significant differences $(P<0.05)$ 


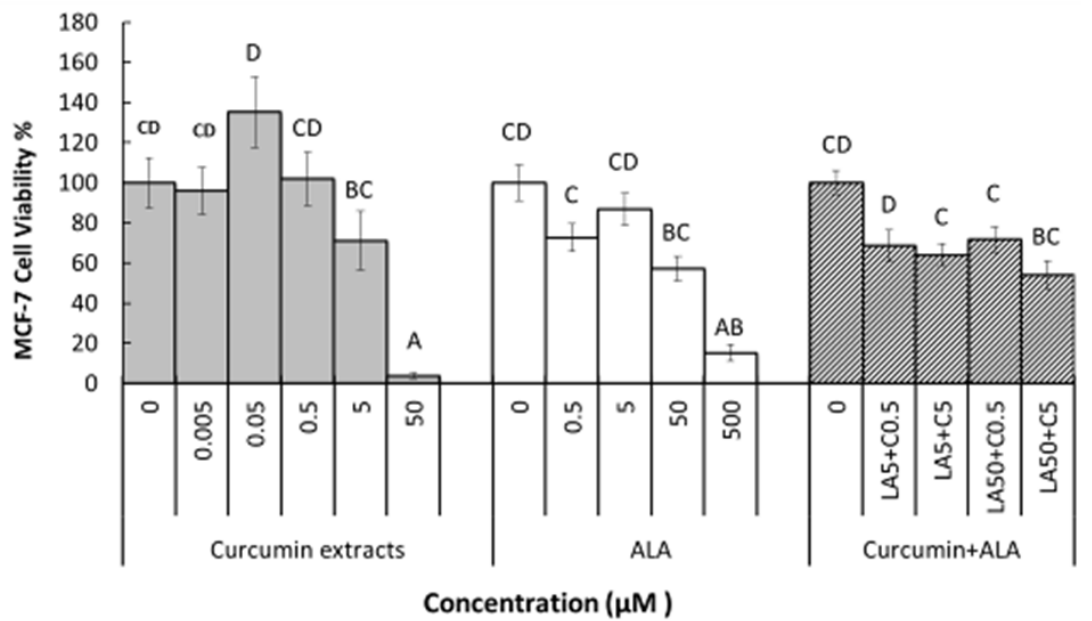

Fig. 4. Effect of curcumin, $\alpha$-Linolenic acid or their combination on MCF-7 cell viability MCF-7 cells were treated with curcumin ALA or combinations for $72 \mathrm{hr}$. Bars show means +/- SEM. Different letters indicate significant differences $(P<0.05)$

\section{DISCUSSION}

\subsection{Extraction Yield and Antioxidant Activity}

Under the conditions of this study, curcumin was insoluble in water and $90 \%$ soluble in methanol. The weight-yield for neem extraction with water $(30 \%)$ compares with previous reports of $58 \%$, $19 \%, 17 \%$ and $4 \%$ with water, butanol, ethyl acetate, or hexane solvent $[25,26]$. The high yield obtained in polar solvent was probably due to high solubility of major components of neem in high polarity solvent. Methanol is expected to extract more nonpolar components compared to water.

In the assays described here, multiple dilutions were adopted a precautionary measure for colorimetric analysis, to ensure sample absorbances occur within the linear range of the assay. Secondly, dilutions were adopted to address a more stealthy issue which is the inadvertent precipitate formation when a concentrated extract is added to an assay system. Where a system behaves ideally, then dilutions should have no effect on final TAC results.

Estimates for TAC (Fig. 1, Table 2) differ according to different assays which are expected since different assays employ different chemistries, and solvent conditions $[39,46]$. For such reasons, multiple methods are recommended for TAC assessment [46]. The performances of different assays may be difficult to compare quantitatively also because each laboratory has developed its own standard operating procedures for analysis whereas a wide variety of conditions affect assay results, e.g. assay time, sample volume, wave-length, and the type of reference antioxidants used. We found the antioxidant activity for trolox was unaffected at $\mathrm{pH} 4.0-\mathrm{pH} 10.0$ whereas gallic acid showed rising antioxidant activity with increasing $\mathrm{pH}$ so the former maybe preferable as a standard [47]. The Folin assay, formerly used to determine TPC in food products, is a suitable general assay for antioxidants [41]. Both the ABTS and DPPH assays are widely used also due to their high sensitivity, short analysis times and high reproducibility. Studies using ABTS and DPPH assay typically adopt trolox as reference antioxidant $[39,40]$. Here, all 4-assays were calibrated with gallic acid and trolox as reference compounds to allow a comparison of results.

The antioxidant methods could be ranked according to molar absorptivity values (Table 1), but the ranking differed when trolox or gallic was used as references. A further ranking was possible based on values for the MDC which takes account of the precision for different methods (eq. 3). Data from Table 1 is should not pit one assay method against another because different assays emphasise different antioxidant characteristics [46].

The antioxidant capacity of neem leaf extract was reported previously [23-27] but no previous 
study employed all the four assays used in the current paper. The free radical quenching capacity for neem leaf water extract for DPPH and $A B T S$ radicals produced $\mathrm{IC}_{50}$ estimates of $26.5 \mu \mathrm{g} / \mathrm{ml}$ and $96 \mathrm{mmol} / 100 \mathrm{~g}$ [23] which are 3-4 fold higher than values reported in the current study. We found also that $\mathrm{IC}_{50}$ values were 2-fold lower for ABTS as compared to the DPPH assay (Table 2), which suggests that former may be more sensitive towards water extractable antioxidants from neem leaf. Ghimire et al. [26] reported the total phenols content for neem leaf water extract as 66.37 (mg GAE/g) equivalent to $39(\mathrm{mmol} \mathrm{GAE} / 100 \mathrm{~g})$ or $6.6 \% \mathrm{w} / \mathrm{w}$. By contrast, the total phenols content for neem leaf extracts was, $38 \%(\mathrm{w} / \mathrm{w}), 20 \%(\mathrm{w} / \mathrm{w})$ or $15 \%(\mathrm{w} / \mathrm{w})$ using ethanol, ethyl acetate or methanol as solvent, respectively [24]. Others reported a total phenols content ranging from $9.6 \%-11.5 \% \mathrm{w} / \mathrm{w}$ for water, methanol and ethyl acetate neem leaf extracts [25]. The total phenols value from the current study was $4.5 \%(\mathrm{w} / \mathrm{w})$ or $27(\mathrm{mmol}$ $\mathrm{GAE} / 100 \mathrm{~g}$ ) which is in fair agreement with reported literature values. Moreover, extraction using nonpolar solvents is expected to increase the recovery of Total Phenols and polyphenols $[25,26]$.

Using curcumin dissolved in ethanol the $\mathrm{IC}_{50}$ was $34.86 \mu \mathrm{g} / \mathrm{ml}$ from the DPPH assay or $18.97 \mu \mathrm{g} /$ $\mathrm{ml}$ for the ABTS assay [19] as compared with values of $7.8 \mu \mathrm{g} / \mathrm{ml}$ and $7.5 \mu \mathrm{g} / \mathrm{ml}$ (this study) with methanol solvent, respectively. Interestingly the antioxidant capacities noted in Fig. 2 and Table 2 for neem and curcumin are comparable to values reported for other herbals and traditional medicines; a survey of 3500 natural agents found that herbals and traditional medicines had the highest antioxidant capacity ranging from $230-1448 \mathrm{mmol} / 100 \mathrm{~g}$ on a TE basis [10].

\subsection{Cell Viability}

Omega-3 fatty acids inhibit the proliferation of MCF-7 (ER+) cells and the order of effectiveness was EPA $=$ DHA > ALA [3,4]. Nevertheless ALA is considered unique in terms of the ability to substantiate anticancer effects based on population studies [4]. A $24 \mathrm{hr}$. treatment with $75 \mu \mathrm{M}$ of ALA produced $55 \%$ inhibition of MCF-7 cells [4]. However, treatment with $50 \mu \mathrm{M}$ ALA for 5-days reduced MCF-7 proliferation by 33\% [48] and a seven day treatment with $30 \mu \mathrm{M}$ ALA reduced cell growth by $30 \%$ [3]. In the current study, the $50 \%$ inhibitory concentration for ALA $\left(\mathrm{IC}_{50}\right)$ was $50 \mu \mathrm{M}$ with $72 \mathrm{hrs}$ treatment (Fig. 3).
The $\mathrm{IC}_{50}$ for curcumin inhibition of MCF-7 was reported previously as, $31.1 \mu \mathrm{M}, 21.3 \mu \mathrm{M}$ or 11.3 $\mu \mathrm{M}$ for cells treated for 24,48 or $72 \mathrm{hrs}[32,34]$. Another literature $\mathrm{IC}_{50}$ value for curcumin using MCF-7 was $60 \mu \mathrm{M}$ following $48 \mathrm{hr}$ treatment [35]. These results compare with our curcumin $\mathrm{IC}_{50}$ of $7.2 \mu \mathrm{M}$ for $72 \mathrm{hr}$ exposure. There is only one relevant literature study of ethanoic neem leaf extract (ENLE) on MCF-7 cells [36] which found that cell viability was reduced by $\sim 50 \%$ with 400 $\mu \mathrm{g} / \mathrm{ml}$ extract (2.4 $\mu \mathrm{M}$ GAE). By comparison, our study found $\mathrm{IC}_{50}$ was $17.8 \mu \mathrm{M}$ (GAE) using a water neem extracts.

To summarize, the present paper confirms that ALA, neem and curcumin are all inhibitory for MCF-7 cells individually. $\mathrm{IC}_{50}$ estimates for the individual components were similar to values from past studies for ALA [3,4], curcumin $[32,34,35]$ or neem [36]. However, this appears to be the first published report to compare neem, curcumin and ALA anticancer properties within a single study. The results indicate that curcumin, neem leaf extract and ALA inhibit MCF-7 cell proliferation in a concentration-dependent manner and that the order of effectiveness was tentatively, curcumin $>$ neem leaf water extract $>$ ALA.

Synergistic interactions between DHA and curcumin were examined recently [49] but no combination studies involving ALA, neem or curcumin appear to be available. In-vitro studies and research using rodent models showed that n-3 fatty acids inhibit breast cancer cells via multiple pathways including, the modification of membrane composition, inhibition of cyclooxygenases or activation of PPAR [5-8]. The findings of the current combination study supports the hypothesis that lipid peroxidation may be implicated anticancer effect of ALA [5-8]. Combination treatments using ALA and curcumin or neem on MCF-7 cells found no improvements compared to individual treatments.

\section{CONCLUSION}

This study confirms that curcumin and neem are substantive antioxidant materials comparable to other herbal and traditional medicinal agents [10]. In-vitro test using MCF-7 cells indicated that ALA, curcumin and neem leaf extract produce a concentration-dependent inhibition of cancer cell growth. Combination treatments using ALA and curcumin or ALA and neem extract, resulted in a significant loss in efficacy of each agent. The findings are consistent with past literature 
suggesting that lipid peroxidation and oxidative stress may be negative risk factors for breast cancer and that antioxidants may on some occasions impair rather than support other therapies [28-30]. It is not possible to eliminate other possible underlying causes for the observed findings. There are further limitations to this study. The design of this study did not extend to a formal analysis of interactions using isobolograms. The study was also an in-vitro study with all the usual well-known limitations. Though in-vitro findings may provide a rational for other studies, the interpretations of data should not be extrapolated to more complex systems such as animal models or human studies. The results obtained with MCF-7 cells should be examined with other cells lines including MCF-10A epithelial cells. Interestingly, a recent study showed that a combination of curcumin and ALA increased the synthesis of n-3 fatty acids in the brain [50]. More extensive studies will be needed to improve current understanding of the effect of antioxidants on ALA anticancer activity.

\section{CONSENT}

The study is an in-vitro design and no consent issues are applicable.

\section{ETHICAL APPROVAL}

The study is an in-vitro design and no ethical approval was needed.

\section{COMPETING INTERESTS}

Authors have declared that no competing interests exist.

\section{REFERENCES}

1. Globocan. Breast cancer estimated incidence, mortality and prevalence worldwide in 2012; 2015.

Available:http://globocan.iarc.fr/Pages/fact sheets cancer.aspx [cited 2015 Jan]

2. Zheng JS, Hu XJ, Zhao, YM, Yang J, Li D, Intake of fish and marine n-3 polyunsaturated fatty acids and risk of breast cancer: Meta-analysis of data from 21 independent prospective cohort studies. The BJM. 2013;346:f3706.

3. Grammatikos SI, Subbaiah PV, Victor TA, Miller WM. N-3 and n-6 fatty-acid processing and growth effects in neoplastic and non-cancerous human mammary epithelial-cell lines. Brit J Cancer. 1994; 70(2):219-227.

4. Wiggins AK, Kharotia S, Mason JK, Thompson LU. Alpha-Linolenic acid reduces growth of both triple negative and luminal breast cancer cells in high and low estrogen environments. Nutr Cancer. 2015;67(6):1001-9.

5. Welsch CW. Review of the effects of dietary fat on experimental mammary gland tumorigenesis: Role of lipid peroxidation. Free Radic Biol Med. 1995; 18(4):757-73.

6. Stoll BA. n-3 fatty acids and lipid peroxidation in breast cancer inhibition. Br. J. Nutr. 2002;87(3):193-198.

7. Gago-Dominguez M, Jiang X, Castelao JE. Lipid peroxidation, oxidative stress genes and dietary factors in breast cancer protection: A hypothesis. Breast Cancer Res. 2007;9(1):201.

8. Das UN. Essential fatty acids enhance free radical generation and lipid peroxidation to induce apoptosis of tumor cells. Clin Lipidol. 2011;6(4):463-489.

9. Anderson BM, Ma DWL. Are all n-3 polyunsaturated fatty acids created equal? Lipids in Health and Disease 8 [Review]; 2009.

Available:http://www.ncbi.nlm.nih.gov/pmc/ articles/PMC3224740/ [cited 2014 Oct]

10. Carlsen $\mathrm{MH}$, Halvorsen $\mathrm{BL}$, Holte $\mathrm{K}$, Bøhn SK, Dragland S, Sampson L, Willey C, Senoo H, Umezono Y, Sanada C, Barikmo I, Berhe N, Willett WC, Phillips KM, Jacobs DR Jr, Blomhoff R. The total antioxidant content of more than 3100 foods, beverages, spices, herbs and supplements used worldwide. Nutr J. 2010;9.

11. Shanmugam MK, Rane G, Kanchi MM, Arfuso F, Chinnathambi A, Zayed ME, Alharbi SA, Tan BK, Kumar AP, Sethi G. The multifaceted role of curcumin in cancer prevention and treatment. Molecules. 2015;20(2):2728-69.

12. Rahmani AH, Al Zohairy MA, Aly SM, Khan MA. Curcumin: A potential candidate in prevention of cancer via modulation of molecular pathways. BioMed Res Int; 2014.

Available:http://dx.doi.org/10.1155/2014/76 1608 [cited 2014; 761608]

13. Teiten $M H$, Eifes $S$, Dicato $M$, Diederich $M$. Curcumin-the paradigm of a multi-target natural compound with applications in 
cancer prevention and treatment. Toxins (Basel). 2010;2(1):128-62.

14. Ravindran J, Prasad S, Aggarwal BB. Curcumin and cancer cells: How many ways can curry kill tumor cells selectively? Aaps J. 2009;11(3):495-510.

15. Biswas K, Chattopadhyay I, Banerjee RK, Bandyopadhyay U. Biological activities and medicinal properties of neem (Azadirachta indica). Current Science. 2002;82(11): 1336-1345.

16. Atawodi SE, Atawodi JC. Azadirachta indica (neem): A plant of multiple biological and pharmacological activities. Phytochem Rev. 2009;8(3):601-620.

17. Anyaehie UB. Medicinal properties of fractionated acetone/water neem [Azadirachta indica] leaf extract from Nigeria: A review. Niger. J. Physiol. Sci. 2009;24(2):157-9.

18. Jayaprakasha GK, Rao LJ, Sakariah KK. Antioxidant activities of curcumin, demethoxycurcumin and bisdemethoxycurcumin. Food Chem. 2006; 98(4):720-724.

19. Ak T, Gulcin I, Antioxidant and radical scavenging properties of curcumin. Chem Biol Interact. 2008;174(1):27-37.

20. Dairam A, Fogel R, Daya S, Limson JL. Antioxidant and iron-binding properties of curcumin, capsaicin, and S-Allylcysteine reduce oxidative stress in rat brain homogenate. J Agric Food Chem. 2008; 56(9):3350-3356.

21. Shang Y-J, Jin Xiao-Ling, Shang X-L, Tang J-J, Liu G-Y,Dai F, Qian Y-P, Fan G-J, Liu Q, Zhou B. Antioxidant capacity of curcumin-directed analogues: Structureactivity relationship and influence of microenvironment. Food Chem. 2010; 119(4):1435-1442.

22. Li Q, Chen J, Luo S, Xu J, Huang Q, Liu T. Synthesis and assessment of the antioxidant and antitumor properties of asymmetric curcumin analogues. Eur $\mathrm{J}$ Med Chem. 2015;93:461-469.

23. Sithisarn P, Supabphol R, Gritsanapan W. Antioxidant activity of Siamese neem tree (VP1209). J. Ethnopharmacol. 2005;99(1): 109-112.

24. Manikandan $\mathrm{P}$, Anandan $\mathrm{R}$, Nagini $\mathrm{S}$, Evaluation of Azadirachta indica leaf fractions for in vitro antioxidant potential and protective effects against h202induced oxidative damage to pBR322 DNA and red blood cells. J. Agric. Food Chem. 2009;57(15):6990-6996.
25. Ghimeray AK, Jin C-W, Ghimire BK, Cho $\mathrm{DH}$. Antioxidant activity and quantitative estimation of azadirachtin and nimbin in Azadirachta indica A. Juss grown in foothills of Nepal. Afr. J. Biotechnol. 2009;8(13):3084-3091.

26. Ghimire BK, Seong ES, Kim EH, Ghimeray AK, Yu CY, Ghimire BK, III Min C. A comparative evaluation of the antioxidant activity of some medicinal plants popularly used in Nepal. J. Med. Plants Res. 2011;5(10):1884-1891.

27. Pangjit $K$, Tantiphaipunwong $P$, Sajjapong W, Srichairatanakool S. Iron-chelating, free radical scavenging and anti-proliferative activities of Azadirachta indica. J Med Assoc Thai. 2014;97(Suppl 4):S36-43.

28. Chajes V, Sattler W, Stranzl A, Kostner GM. Influence of $n-3$ fatty-acids on the growth of human breast-cancer cells invitro - relationship to peroxides and vitamin-e. Breast Cancer Res Treat. 1995;34(3):99-212.

29. Chamras H, Ardashian A, Heber, D, Glaspy JA. Fatty acid modulation of MCF-7 human breast cancer cell proliferation, apoptosis and differentiation. J Nutr Biochem. 2002;13(12):711-716.

30. Edwards IJ, Berquin IM, Sun $H G$, O'Flaherty JT, Daniel, LW, Thomas MJ, Rudel LL, Wykle RL, Chen YQ, Differential effects of delivery of omega- 3 fatty acids to human cancer cells by low-density lipoproteins versus albumin. Clin. Cancer Res. 2004;10(24):8275-8283.

31. Syng-Ai C, Kumari A, Khar A. Effect of curcumin on normal and tumor cells: Role of glutathione and bcl-2. Mol. Cancer Ther. 2004;3(9):1101-1108.

32. Jiang $M$, Huang $O$, Zhang $X$, Xie $Z$, Shen A, Liu $H$, Geng M, Shen K. Curcumin induces cell death and restores tamoxifen sensitivity in the antiestrogen-resistant breast cancer cell lines MCF-7/LCC2 and MCF-7/LCC9. Molecules. 2013;18(1):70120.

33. Jia $T$, Zhang $L$, Duan $Y$, Zhang $M$, Wang G, Zhang J, Zhao Z. The differential susceptibilities of MCF-7 and MDA-MB231 cells to the cytotoxic effects of curcumin are associated with the PI3K/AktSKP2-Cip/Kips pathway. Cancer Cell International. 2014;14:126.

Available:http://www.biomedcentral.com/co ntent/pdf/s12935-014-0126-4.pdf [cited 2015 Sept] 
34. Mirakabad FST, et al. A comparison between the cytotoxic effects of pure curcumin and curcumin-loaded PLGA-PEG nanoparticles on the MCF-7 human breast cancer cell line. Artificial Cells, Nanomedicine, and Biotechnology; 2014.

Available:http://dx.doi.org/10.3109/216914 $\underline{01.2014 .955108}$ [cited 2015 Sept]

35. Lv ZD, Liu XP, Zhao WJ, Dong Q, Li FN, Wang HB, Kong B. Curcumin induces apoptosis in breast cancer cells and inhibits tumor growth in vitro and in vivo. Int J Clin Exp Pathol. 2014;7(6):2818-24.

36. Sharma C, Vas AJ, Goala P, Gheewala TM, Rizvi TA, Hussain A. Ethanolic neem (Azadirachta indica) leaf extract prevents growth of MCF-7 and HeLa cells and potentiates the therapeutic index of cisplatin. J Oncol. 2014;2014:321754321754.

37. Butts WC, Mulvihill HJ. Centrifugal analyzer determination of ascorbate in serum or urine with $\mathrm{Fe} 3+/$ Ferrozine. Clin Chem. 1975;21(10):1493-7.

38. Brand-Williams W, Cuvelier ME, Berset C, Use of a free radical method to evaluate antioxidant activity. Lwt-Food Sci Technol. 1995;28(1):25-30.

39. Thaipong $\mathrm{K}$, Boonprakob $\mathrm{U}$, Crosby $\mathrm{K}$, Cisneros-Zevallos L, Byrne DH. Comparison of ABTS, DPPH, FRAP, and ORAC assays for estimating antioxidant activity from guava fruit extracts. J Food Compost Anal. 2006;19(6-7):669-675.

40. Walker RB, Everette JD. Comparative reaction rates of various antioxidants with ABTS radical cation. J Agric Food Chem. 2009;57(4):1156-61.

41. Ainsworth EA, Gillespie KM. Estimation of total phenolic content and other oxidation substrates in plant tissues using FolinCiocalteu reagent. Nat Protoc. 2007;2(4): 875-7.

42. Vichai V, Kirtikara K. Sulforhodamine B colorimetric assay for cytotoxicity screening. Nature Protocol. 2006;1(3): 1112-6.

43. Sebaugh JL. Guidelines for accurate EC50/IC50 estimation. Pharm Stat. 2010; 10(2):128-34.

44. Bolanos de la Torre AA, Henderson $\mathrm{T}$, Nigam PS, Owusu-Apenten RK. A universally calibrated microplate ferric reducing antioxidant power (FRAP) assay for foods and applications to Manuka honey. Food Chem. 2015;174:119-23.

45. Owusu-Apenten R. Food protein analysis: Quantitative effects on processing. Taylor \& Francis; 2002.

46. Prior RL, Wu X, Schaich K. Standardized methods for the determination of antioxidant capacity and phenolics in foods and dietary supplements. J Agric Food Chem. 2005;53(10):4290-302.

47. Wong C, Cheung WSM, Lau YY, Bolanos de la Torre AA, Owusu-Apenten RK. A FRAP assay at $\mathrm{pH} 7$ unveils extra antioxidant activity from green, blank, white and rooibos tea but not apple tea; 2015.

Available:http://verizonaonlinepublishing.co m/FnNPDF/FoodandNutritionReport3.pdf [cited 2015 Sept]

48. Truan JS, Chen JM, Thompson LU. Flaxseed oil reduces the growth of human breast tumors (MCF-7) at high levels of circulating estrogen. Mol Nutr Food Res. 2010;54(10):1414-21.

49. Altenburg JD, Bieberich AA, Terry C, Harvey KA, Vanhorn JF. Xu Z, Davisson JV, Siddiqui RA. A synergistic antiproliferation effect of curcumin and docosahexaenoic acid in SK-BR-3 breast cancer cells: unique signaling not explained by the effects of either compound alone. BMC Cancer. 2011;11: 149.

50. Wu A, Noble EE, Tyagi E, Ying Z, Zhuang Y, Gomez-Pinilla F. Curcumin boosts DHA in the brain: Implications for the prevention of anxiety disorders. Biochim Biophys Acta. 2015;1852(5):951-961.

(0) 2016 Cheung et al.; This is an Open Access article distributed under the terms of the Creative Commons Attribution License (http://creativecommons.org/licenses/by/4.0), which permits unrestricted use, distribution, and reproduction in any medium, provided the original work is properly cited.

Peer-review history:

The peer review history for this paper can be accessed here: http://sciencedomain.org/review-history/12881 